\title{
An Ex-Post Analysis of the 2004 Olympic Effect
}

\author{
By Gregory T. Papanikos*
}

\begin{abstract}
This paper evaluates the effects of the Olympic Games of 2004 hosted in Athens on Greece's Gross Domestic Product (GDP), as estimated in Papanikos (1999). The estimates were made in 1997 for a period of fourteen years, 1998-2011, based on various scenarios. During this period two events have had a great impact on GDP that could have been predicted in 1997. Firstly, Greece adopted the euro in 2002, and even though this was pretty much a possibility in 1997, but not of course a certainty, the most important effect of the euro would have come from its exchange value vis-a-vis major currencies of countries with Greece was trading. This included tourism. Despite what many economists thought at the time, the introduction of the euro was not accompanied by a devaluation, but by unprecedented overvaluation. This had a negative impact on Greek GDP. Secondly, the Great Recession hit the Greek economy hard starting in 2008. These two effects had a negative impact on Greek GDP, wiping out the expected positive effects of the Olympic Games.
\end{abstract}

Keywords: Olympic Games, GDP, Athens 2004, euro, great recession

\section{Introduction}

Hosting the Olympic Games has many effects on an economy. The effect on Gross Domestic Product (GDP), and therefore employment, is considered the most important one. In 1999, the Research Institute of Tourism (RIT) published a book which had estimates of the effect of Athens in 2004 on Greek GDP from 1998 to 2011 (Papanikos 1999). A summary is presented in Kartakoullis et al. (2003) and Papanikos (2020). The purpose of this short note is to provide an ex-post assessment of these estimates. It seems that the positive effect of hosting Olympic Games on GDP is through an increase in exports as has been demonstrated in Rose and Spiegel (2011). Also, Kasimati and Dawson (2009) found a positive effect on Greek economic growth during the preparation period as well as in the immediate post-Olympic period, but modest effects, if any at all, in the long-term. These studies are within the spirit of this study. I assume the positive effects and I also assume that the estimates made in my 1999 study were realized. This paper, then, aims to estimate the exact magnitude of the Olympic effect on Greek GDP.

The literature on the economics and other issues of Olympic Games is huge. I do not intend to present a review of this literature. A number of studies have been published in this Journal on various aspects of Olympic Games, and ATINER has published two books based on papers presented at its various conferences (Papanikos 2003, 2004a). One of these conferences was organized in collaboration with the International Association of Sports Economics (IASE) and the Panhellenic

*President, Athens Institute for Education and Research, Greece; Honorary Professor of Economics, University of Stirling, UK; and Professor, MLC Ljubljana, Slovenia. 
Association of Sports Economists and Managers (PASEM). In what follows, I review some of these publications as an indication of the subjects covered under the rubric of Olympic Games studies.

In an interesting paper, Tomecka (2019) gives a different twist to the whole idea of Olympics and medals by connecting to the ancient concepts of good and brave. The idea of Olympic Games transcends sports as is perceived by the common man. It is an ideal that emphasize high spirits and values. This relates very much to the award of the Olympics Games of Athens in 2004 as representing the true spirit and value of Olympic Games.

Another topic of research has been the comparison between ancient and modern Olympic Games. Stefani (2017) compared the athletic performance of athletes in the ancient Olympic Games and modern games. The focus of the paper was on male-female differences in various periods of modern Olympic Games.

Cabralis et al. (2018) evaluated a sports administration training programme of the Trinidad \& Tobago Olympic Committee (TTOC). Their finding was very encouraging because after almost two decades, the graduate of the programme held strategic sports administrator positions in various organizations. Many universities and organizations offer education programmes that relate to Olympic Games and this study is an example.

Costas (2017) is another study which emphasizes the education and training aspects of the Olympic Games legacy, but this time for the London Olympic Games and the sport of swimming for young children. The author emphasizes the pupil's voice, "... as a pedagogical approach to inform curriculum design."

Nicoliello (2021) examines the New Agenda of 2020+5 which was approved by the International Olympic Committee. This new strategic roadmap consisted of 15 recommendations. There is a call to "strengthen the uniqueness and the universality of the Olympic Games; foster sustainable Olympic Games; reinforce athletes' rights and responsibilities; continue to attract the best athletes; further strengthen safe sports and the protection of clean athletes; enhance and promote the Road to the Olympic Games; coordinate the harmonisation of the sports calendar; grow digital engagement with people; encourage the development of virtual sports and further engage with video gaming communities; strengthen the role of sport as an important enabler for the UN Sustainable Development Goals; strengthen the support to refugees and populations affected by displacement; reach out beyond the Olympic community; continue to lead by example in corporate citizenship; strengthen the Olympic Movement through good governance; innovate revenue generation models."

The most important of Olympic Games research is the economics of Olympic Games even though the social impacts should not be underestimated (Máte 2018). Bakkenbüll and Dilger (2020) did an economic study of the willingness of German people to host Olympic Games in their own country. Using the classical methodology of willingness to pay, they found that Germans were willing to pay 3.57 billion euro to host the games.

Kasimati (2015) has looked at the post-Olympic use of the Olympic venues of Athens since it was hosted there in 2004. She found that their utilization was slow 
and ineffective. As she argued, years after the games the benefits from the venues are to be seen.

The paper is organized on five sections including this introduction. Section two presents and discusses the estimates of Papanikos' (1999) book. In the following section the realized GDP data are compared with the estimates, and as a result, an estimate of the Olympic effect is measured. Section four speculates how the Olympic Games of Athens 2004 could have benefitted more of the Greek economy and what policies were required to achieve this goal.

\section{The Original Ex Ante Estimates}

Table 1 reproduces the data as originally published in Papanikos (1999). The assumption made was that there were three types of expenditures: tourism, investment for the Olympic Games (direct) and administrative expenditures needed for the organization of the Olympic Games of Athens 2004. The last two had no effect after the game and only the tourism continued to contribute to GDP after the games. The assumption made was that these effects lasted till 2011.

Table 1. Effect on GDP and Employment, 1998-2011 (Billions of Constant 1999 Drachmae)

\begin{tabular}{|c|c|c|c|c|c|c|}
\hline Year & $\begin{array}{c}\text { Tourism } \\
(\mathbf{1 . 5})\end{array}$ & $\begin{array}{c}\text { Investment } \\
(\mathbf{1 . 8})\end{array}$ & $\begin{array}{c}\text { Organization } \\
(\mathbf{1 . 2})\end{array}$ & GDPOG & $\begin{array}{c}\text { GDPGROG } \\
(\mathbf{\%})\end{array}$ & $\begin{array}{c}\text { EMPLOG } \\
(\mathbf{0 0 0 s})\end{array}$ \\
\hline 1998 & 62 & 0 & 1 & 63 & 0.2 & 7 \\
\hline 1999 & 134 & 0 & 6 & 140 & 0.4 & 15 \\
\hline 2000 & 211 & 0 & 12 & 223 & 0.6 & 23 \\
\hline 2001 & 278 & 65 & 24 & 367 & 1 & 39 \\
\hline 2002 & 369 & 130 & 48 & 547 & 1.4 & 57 \\
\hline 2003 & 374 & 130 & 96 & 600 & 1.6 & 63 \\
\hline 2004 & 436 & 65 & 269 & 770 & 2 & 81 \\
\hline 2005 & 407 & 0 & 0 & 407 & 1.1 & 43 \\
\hline 2006 & 322 & 0 & 0 & 322 & 0.9 & 34 \\
\hline 2007 & 253 & 0 & 0 & 253 & 0.7 & 27 \\
\hline 2008 & 170 & 0 & 0 & 170 & 0.4 & 18 \\
\hline 2009 & 178 & 0 & 0 & 178 & 0.5 & 18 \\
\hline 2010 & 93 & 0 & 0 & 93 & 0.2 & 10 \\
\hline 2011 & 92 & 0 & 0 & 92 & 0.2 & 10 \\
\hline & 3379 & 390 & 456 & 4225 & 11.2 & 445 \\
\hline
\end{tabular}

Source: Papanikos (1999, Table 5, p. 112).

For each type of expenditure, it was assumed an ad hoc multiplier effect. The tourism multiplier was 1.5 , the investment multiplier was assumed equal to 1.8 and the administration expenditures multiplier was the lowest and equal to 1.2 (in parenthesis in the table). All expenditures are in constant (1999) billions of drachmae. More than $60 \%$ of the administrative expenditures were realized during the year of the games, 2004. Employment was estimated using the average productivity in the service sector, which, in 1999, was equal to 9.5 million 
drachmae. The employment issue at the microeconomic level is discussed in Papanikos (2004b).

According to the estimates of Table 1, the maximum effect of Olympic Games in terms of GDP growth was $2 \%$ in 2004. The accumulated growth rate of the $1998-2011$ period was $11.2 \%$ or $0.8 \%$ per year.

Measured in units of the national currency at the time (i.e., drachmae), it was estimated that GDP would have grown by 4.2 trillion of drachmae during this period coming from tourism (3.4 trillion or $80 \%)$, from investment ( 0.4 trillion drachmae or $9.2 \%)$ and from organizational expenditures ( 0.5 trillion drachmae or $10.8 \%)$.

In terms of employment, the Olympic Games would have created 445,000 jobs during the 1998-2011 period.

The GDP growth rates of the Olympic effect are used in the next section to provide estimates of the ex-post GDP effect.

\section{Ex-Post Estimates of the Olympic Effect}

Table 2 uses the actual GDP data of the 1998-2011 period in billions of constant (2015) euro and the growth rates of the Olympic effect of the previous section to estimate the total GDP effect.

Table 2. The Ex-Post Effect

\begin{tabular}{|l|c|c|c|c|}
\hline Year & $\begin{array}{c}\text { GDP } \\
(\text { Bn 2015 } \boldsymbol{~})\end{array}$ & $\begin{array}{c}\text { GDPGR } \\
(\boldsymbol{\%})\end{array}$ & $\begin{array}{c}\text { GDPGROG } \\
(\boldsymbol{\%})\end{array}$ & $\begin{array}{c}\text { GDPOG } \\
\text { (Bn Constant } \boldsymbol{\epsilon})\end{array}$ \\
\hline 1998 & 169.5 & 3.86 & 0.2 & 0.339 \\
\hline 1999 & 174.7 & 3.07 & 0.4 & 0.6988 \\
\hline 2000 & 181.6 & 3.95 & 0.6 & 1.0896 \\
\hline 2001 & 189.1 & 4.13 & 1 & 1.891 \\
\hline 2002 & 196.5 & 3.91 & 1.4 & 2.751 \\
\hline 2003 & 207.9 & 5.80 & 1.6 & 3.3264 \\
\hline 2004 & 218.4 & 5.05 & 2 & 4.368 \\
\hline 2005 & 219.7 & 0.60 & 1.1 & 2.4167 \\
\hline 2006 & 232.1 & 5.64 & 0.9 & 2.0889 \\
\hline 2007 & 239.7 & 3.27 & 0.7 & 1.6779 \\
\hline 2008 & 238.9 & -0.33 & 0.4 & 0.9556 \\
\hline 2009 & 228.6 & -4.31 & 0.5 & 1.143 \\
\hline 2010 & 216.1 & -5.47 & 0.2 & 0.4322 \\
\hline 2011 & 194.2 & -10.13 & 0.2 & 0.3884 \\
\hline \multicolumn{2}{|l|}{ Total (1998-2011) } & 19.04 & 11.20 & 23.57 \\
\hline \multicolumn{2}{|l}{ Average (1998-2011) } & 1.36 & 0.80 & 1.68 \\
\hline
\end{tabular}

The total effect was 24 billion of 2015 euro or $1.68 \%$ per year. However, this is double the figure found in Table 1 and might be the result of two important events during the period under consideration. 
The Olympic effect on GDP is very difficult to measure because during this period, 1998-2011, two other very significant events happened which are assumed to have had very important and unprecedented effects in peace years.

Firstly, in 2002, Greece became one of the initial members of the Eurozone. I have analyzed this effect elsewhere, the ex-ante in Papadopoulos and Papanikos (1997, 2002) and the ex-post in Papanikos (2015a, 2022). I will not repeat the discussion here, but I should emphasize something that relates to the tourism effect.

International tourism expenditures are considered exports which is the effect that the study of Rose and Spiegel (2011) found as the most important effect of the Olympic legacy. However, this very much depends on the exchange rate. If there is an overvaluation (undervaluation) of euro, then the tourism effect, as had been estimated in Table 1, would have been lower (higher). For the estimates of the tourism effect, it was assumed that the exchange rate would have been relatively stable. However, as it turned out, it was far from stable.

Figure 1 shows the nominal exchange rate of units of US dollars required to buy one euro. In 2002, the first year of euro in actual circulation, less than one dollar was required to buy one euro. In the year of the Olympic Games in 2004, the euro reached record levels of overvaluation and fluctuated between 1.2 and 1.4 of a US dollar. The euro appreciated even further reaching the highest-ever rate of 1.6 dollars. Throughout the $2008-2011$ period it remained at very high rates. This had a detrimental effect on Greek tourism.

Figure 1. Nominal Exchange Rate of Euro/Dollar

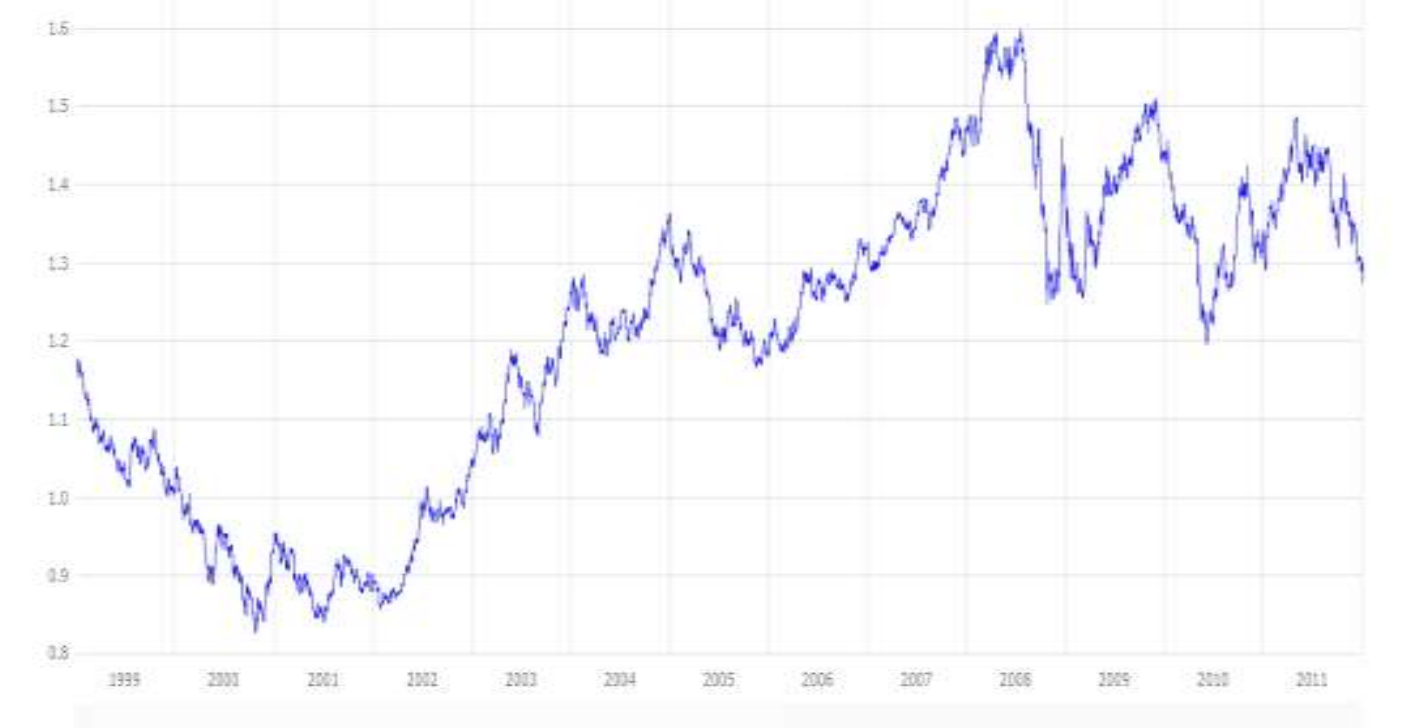

Source: European Central Bank.

Secondly, the Great Recession of 2008 hit Greece very badly. Never before in peace years did the Greek GDP decrease so much, as shown in Table 2. The last four years of the alleged Olympic effect, the Greek GDP was constantly declining at an increasing rate. In 2008 by $0.33 \%$; in 2009 by $4.31 \%$; in 2010 by $5.47 \%$ and 
in 2011 by $10.13 \%$. I have extensively researched the effects of the Great Recession on the Greek economy (see Papanikos 2015a-2015j, 2014a-c) and the main conclusion was that international factors and internal political developments can explain why the Greek economy was hit so hard, relative to the other Eurozone countries.

Neither of these two impacts could have been predicted in 1997. Most would have expected that the euro would have depreciated relative to the US dollar because of the uncertainly surrounding the new currency; the opposite happened during the time period under examination here. Of course, the Great Recession, and primarily the extent of its effect, could not have been predicted in 1997 with the information available at the time.

\section{The Benefits from Hosting Olympic Games}

It is true that Athens was transformed because of the Olympic Games of 2004. New infrastructure was built which has had a permanent effect on people's lives. The new airport, metro system, ring roads and many other such major improvements have increased the quality of living in the city. Consequently, this has increased the attractiveness of the city and more tourists are coming because of that. Ziakas and Boukas (2014) did a study using qualitative data obtained from semi-structured interviews of nine city officials and tourism administrators whom concluded that it is not too late to implement post-event leveraging. They recommend the development of a strategic framework which combines sports and culture.

The above emphasis on marketing the legacy of the Olympic Games (as is also explained in Kartakoullis et al. (2003)) does reflect the actual process of how the Games can have a positive effect. The marketing tool is the Games themselves and the world publicity it generates. This positive image is materialized as an economic (GDP) effect through tourism and exports of Greek products. The latter should reflect the culture and the ideals of the spirit of the Games. Selling wine and olive oil in the world market would not have been assisted by the Olympic Games of 2004. This is the reason I considered the international tourism arrivals as the most important and quite possibly the only long-lasting Olympic economic effect in my original study of 1999.

After all, the Olympic Games is not about only money. The economic effects are important, but Olympic Games have their own cultural value by promoting world peace by bringing the youth of the world together, and instead of fighting in the battlefields, they "fight" in the arenas of the Olympic Games.

\section{Conclusions}

Predicting the Olympic Games' economic effect is rather speculative. This paper analyzed the estimates of 1997 made by Papanikos (1999) of the Olympic Games of 2004 on Greek GDP for a period of fourteen years which started in 1998 
and ended in 2011. In total, the GDP effect was found equal to 24 billion euro or 1.68 billion euro per year.

However, these effects should be interpreted with caution, because during the same period, the Greek economy was affected by two major events which have had lasting effects on Greek GDP. Firstly, the introduction of the euro in 2002 and its erratic behavior of its value, vis-a-vis major currencies had a negative impact on Greek GDP. Secondly, the Great Recession hit the Greek economy hard during the last four years (2008-2011) of the fourteen-year period, which coincide with the last years of the Olympic effect on Greek GDP.

The above shows that long-term economic predictions are difficult to be made given that unforeseen factors may undermine any scenario. As such, this is the case of the current pandemic which also hit the Greek economy very hard, especially its tourism sector, but this took place outside of the time framework of the Olympic effect.

\section{References}

Bakkenbüll L-B, Dilger A (2020) Willingness to pay and accept for hosting Olympic Games in Germany. Athens Journal of Sports 7(3): 189-204.

Cabralis S, Foo C, Schaefer G (2018) Where are they now? - A review of the Trinidad \& Tobago Olympic committee sports administrator courses. Athens Journal of Sports 5(1): 53-68.

Costas BP (2017) Sinking, swimming or just treading water. the Olympic legacy from London $2012-4$ years on. Has it made any difference? Pupil voice and an analysis of swimming provision. Athens Journal of Sports 4(1): 35-52.

Kartakoullis N, Papanikos G, Karlis G (2003) City and sport marketing strategy: the case of Athens 2004. The Sport Journal 6(2): 1-6.

Kasimati E (2015) Post-Olympic use of the Olympic venues: the case of Greece. Athens Journal of Sports 2(3): 167-184.

Kasimati E, Dawson P (2009) Assessing the impact of the 2004 Olympic Games on the Greek economy: a small macroeconometric model. Economic Modelling 26(1): 139146.

Máté T (2018) Social impacts of international sport events - Based on experiences from European youth Olympic festival 2017 Györ. Athens Journal of Sports 5(3): 227-242.

Nicoliello M (2021) The new agenda 2020+5 and the future challenges for the Olympic movement. Athens Journal of Sports 8(2): 121-140.

Papadopoulos AP, Papanikos GT (2002) Exchange rate regimes and the linkage between money and output in Greece. Journal of Policy Modelling 24(2): 103-117.

Papadopoulos AP, Papanikos GT (1997) Single European currency: implications for Greek industry. Part of the Project The Future of Greek Industry. Ref. No.: A/EПB 12054/403/Ф.6.1.3. Athens: Greek Government (Ministry of Development).

Papanikos GT (1999) Tourism impact of the 2004 Olympic Games. (In Greek). Athens: Tourism Research Institute.

Papanikos GT (2003) The economics of professional sports and Olympic Games. Athens: Athens Institute for Education and Research (ATINER).

Papanikos GT (2004a) The economics and management of mega athletic events: Olympic Games, professional sports, and other essays. Athens: Athens Institute for Education and Research (ATINER). 
Papanikos GT (2004b) The determinants of employment creation in small regional firms. International Regional Science Review 27(2): 187-204.

Papanikos GT (2014a) The economic crisis of Greece: a class analysis in support of memorandums. (In Greek). Athens: ATINER.

Papanikos GT (2014b) Greek trade unions, the euro and the current crisis. The Singapore Economic Review 59(4): S1-S2.

Papanikos GT (2014c) The Greek sovereign debt: are there really any options? Romanian Journal of Fiscal Policy 5(2): 1-25.

Papanikos GT (2015a) The real exchange rate of euro and Greek Economic growth. Journal of Economic Asymmetries 12(Nov): 100-109.

Papanikos GT (2015b) Taxing wealth and only wealth in an advanced economy with an oversized informal economy and vast tax evasion: the case of Greece. Vierteljahrshefte zur Wirtschaftsforschung, DIW Berlin 84(3): 85-106.

Papanikos GT (2015c, May 27) A Grexit would not be a catastrophe for all. LSE European Politics and Policy (EUROPP) Blog.

Papanikos GT (2015d, April 13) The Greek economic crisis: facts and myths. Available at: http://www.atiner.gr/gtp/The Nature of Greek Economic Crisis.pdf.

Papanikos GT (2015e, March 4) The long and winding road to reform Greece's economy. The Conversation.

Papanikos GT (2015f, February 4) Greece's new debt deal may appease creditors but it won't help the economy. The Conversation.

Papanikos GT (2015g, January 26) The "Works and Days" of Syriza's first week in power. Available at: http://www.atiner.gr/gtp/The Works and Days of Syriza's first week in power.pdf.

Papanikos GT (2015h, January 26) With Greece backing euro but Syriza in government, another election may beckon. The Conversation and New Statesman.

Papanikos GT (2015i, January 22) ECB decision should be good news for Greece, but Syriza will get in the way. The Conversation.

Papanikos GT (2015j, January 6) Hard evidence: can Germany throw Greece a lifeline and save the euro? The Conversation.

Papanikos GT (2020) The participation legacy at Olympic Games. Athens Journal of Sports 7(4): 251-262.

Papanikos GT (2022) Greece in the Eurozone: an evaluation of the first two decades. Athens Journal of Business and Economics (forthcoming).

Rose AK, Spiegel MM (2011) The Olympic effect. The Economic Journal 121(553): 652677.

Stefani R (2017) Kinesiology analysis of athletics at the Ancient Olympics and of performance differences between male and female Olympic champions at the Modern Games in running, swimming and rowing. Athens Journal of Sports 4(2): 123-138.

Tomecka M (2019) The elite of "Kalos Kagathos" in Poland. Athens Journal of Sports 6(1): $29-44$

Ziakas V, Boukas N (2014) Post-event leverage and Olympic legacy: a strategic framework for the development of sport and cultural tourism in post-Olympic Athens. Athens Journal of Sports 1(2): 87-102. 